\title{
Novel Synthesis of 2-Aryl and 2,3-Disubstituted Indoles by Modified Double Elimination Protocol
}

\author{
Govindarajulu Babu, Akihiro Orita, and Junzo Otera* \\ Department of Applied Chemistry, Okayama University of Science, \\ Ridai-cho, Okayama 700-0005, Japan \\ otera@high.ous.ac.jp
}

\section{Supporting Information}

\section{Novel Synthesis of 2-Aryl and 2,3-Disubstituted Indoles by Modified Double Elimination protocol}

Compound 1: A $300 \mathrm{~mL}$ flask was charged with 2-nitro-benzylchloride (8.56 g, 49.8 $\mathrm{mmol})$, benzenesulfinic acid sodium salt dihydrate $(9.82 \mathrm{~g}, 59.8 \mathrm{mmol})$ and DMF (200 $\mathrm{mL})$. After the mixture had been stirred at $80^{\circ} \mathrm{C}$ for $12 \mathrm{~h}$, the reaction mixture was cooled to room temperature and poured into cold water. The product thus precipitated was filtered, washed with water, dried in vacuo and recrystallized from dicholomethanehexane to give $13.39 \mathrm{~g}$ of 2-nitro-benzylsulfone ${ }^{1}(97 \%)$ as a colorless solid. ${ }^{1} \mathrm{H}$ NMR $\quad\left(500 \mathrm{MHz}, \mathrm{CDCl}_{3}\right) \delta: 7.91(\mathrm{dd}, 1 \mathrm{H}, J=8.5,1.5 \mathrm{~Hz}), 7.69-7.45(\mathrm{~m}, 8 \mathrm{H}), 4.95(\mathrm{~s}$, $2 \mathrm{H}) ;{ }^{13} \mathrm{C}$ NMR $\left(125 \mathrm{MHz}, \mathrm{CDCl}_{3}\right) \delta: 149.1,137.7,134.2,134.1,133.3,130.0,129.2$, $128.3,125.4,122.9,58.4$.

A $200 \mathrm{~mL}$ flask was charged with 2-nitro-benzylsulfone (5.54 g, $20 \mathrm{mmol})$, tin (10 g, $84.2 \mathrm{mmol})$ in methanol $(50 \mathrm{~mL})$ and con. $\mathrm{HCl}(50 \mathrm{~mL})$. After the mixture had been stirred at $40^{\circ} \mathrm{C}$ for $6 \mathrm{~h}$, the reaction mixture was cooled to room temperature and poured into the mixture of ice and $10 \% \mathrm{NaOH}$ solution $(500 \mathrm{~mL})$. The product thus precipitated was filtered, washed with water, dried in vacuo and recrystallized from ethyl acetate-ethanol $(1: 1)$ to give $4.49 \mathrm{~g}$ of $\mathbf{1}^{2}(91 \%)$ as a colorless solid. ${ }^{1} \mathrm{H}$ NMR $\left(500 \mathrm{MHz}, \mathrm{CDCl}_{3}\right) \delta: 7.75(\mathrm{~d}, 2 \mathrm{H}, \quad J=7.0 \mathrm{~Hz}), 7.64(\mathrm{t}, 1 \mathrm{H}, \quad J=7.5 \mathrm{~Hz})$, $7.51(\mathrm{t}, 2 \mathrm{H}, J=7.5 \mathrm{~Hz}), 7.13(\mathrm{t}, 1 \mathrm{H}, J=7.5 \mathrm{~Hz}), 6.76(\mathrm{~d}, 1 \mathrm{H}, \quad J=7.5 \mathrm{~Hz}), 6.60(\mathrm{t}$, $1 \mathrm{H}, \quad J=7.5 \mathrm{~Hz}), 6.53(\mathrm{~d}, 1 \mathrm{H}, J=7.5 \mathrm{~Hz}), 4.35(\mathrm{~s}, 2 \mathrm{H}), 4.27(\mathrm{~s}, 2 \mathrm{H}) ;{ }^{13} \mathrm{C} \mathrm{NMR}(125$ $\left.\mathrm{MHz}, \mathrm{CDCl}_{3}\right) \delta: 146.8,137.6,133.8,132.7,130.0,128.9,128.4,119.1,117.7,113.9$, 60.0 .

Compound 2: A $100 \mathrm{~mL}$ fask was charged with $1(1.24 \mathrm{~g}, 5.03 \mathrm{mmol})$ and 
pyridine $(1.22 \mathrm{~mL}, 15.11 \mathrm{mmol})$ in $\mathrm{CH}_{2} \mathrm{Cl}_{2}(30 \mathrm{~mL})$. Trifluroacetic anhydride $(1.54$ $\mathrm{mL}, 11.06 \mathrm{mmol}$ ) was added at $0{ }^{\circ} \mathrm{C}$. After the mixture had been stirred at room temperature for $2 \mathrm{~h}$, the reaction mixture was quenched by the addition of aqueous $\mathrm{NH}_{4} \mathrm{Cl}$. After extraction with ethyl acetate, the organic layer was dried over $\mathrm{MgSO}_{4}$ and filtered. The solvent was evaporated and the residue was chromatographed (4:6 ethyl acetate / hexane) to give $1.63 \mathrm{~g}$ of $\mathbf{2}(95 \%)$ as a colorless solid. ${ }^{1} \mathrm{H}$ NMR $\quad\left(500 \mathrm{MHz}, \mathrm{CDCl}_{3}\right) \delta: 9.81(\mathrm{~s}, 1 \mathrm{H}), 7.81(\mathrm{~d}, 1 \mathrm{H}, J=8.0 \mathrm{~Hz}), 7.75(\mathrm{~d}, 2 \mathrm{H}, J=$ $7.5 \mathrm{~Hz}), 7.70(\mathrm{t}, 1 \mathrm{H}, \quad J=7.5 \mathrm{~Hz}), 7.55(\mathrm{~d}, 2 \mathrm{H}, J=8.0 \mathrm{~Hz}), 7.45(\mathrm{dt}, 1 \mathrm{H}, J=8.0$, $1.0 \mathrm{~Hz}), 7.14(\mathrm{t}, 1 \mathrm{H}, J=7.5 \mathrm{~Hz}), 6.85(\mathrm{~d}, 1 \mathrm{H}, J=8.0 \mathrm{~Hz}), 4.37(\mathrm{~s}, 2 \mathrm{H}) ;{ }^{13} \mathrm{C}$ NMR $(125$ $\left.\mathrm{MHz}, \mathrm{CDCl}_{3}\right) \delta: 156.3(\mathrm{q}, J=38.1 \mathrm{~Hz}$ ), 136.8, 134.6, 134.5, 132.8, 130.2, 129.3, $128.3,127.2,125.9,121.2,117.1(\mathrm{q}, J=288.8 \mathrm{~Hz}), 59.6$.

Compound 3a: LHMDS (1.0M in THF, $6.8 \mathrm{~mL}, 6.8 \mathrm{mmol})$ was added to a THF solution $(30 \mathrm{~mL})$ of sulfone $2(1.16 \mathrm{~g}, 3.39 \mathrm{mmol})$ at $-78^{\circ} \mathrm{C}$, and the mixture was stirred for $30 \mathrm{~min}$. Benzaldehyde $(0.790 \mathrm{~g}, 7.45 \mathrm{mmol})$ in THF $(6 \mathrm{~mL})$ was added dropwise at this temperature. After an additional $1 \mathrm{~h}, \mathrm{ClP}(\mathrm{O})(\mathrm{OEt})_{2}(1.07 \mathrm{~mL}, 7.45 \mathrm{mmol})$ was added at $-78{ }^{\circ} \mathrm{C}$ and the mixture was stirred at room temperature for $2 \mathrm{~h}$. Potassium $t$ butoxide $(1.65 \mathrm{~g}, 13.56 \mathrm{mmol})$ was added at $0{ }^{\circ} \mathrm{C}$. After the mixture had been stirred at the same temperature for $1 \mathrm{~h}$, the reaction mixture was quenched by the addition of aqueous $\mathrm{NH}_{4} \mathrm{Cl}$. After extraction with ethyl acetate, the organic layer was dried over $\mathrm{MgSO}_{4}$ and filtered. The solvent was evaporated, and the residue was chromatographed (2.5:7.5 ethylacetate / hexane) to give $1.33 \mathrm{~g}$ of $\mathbf{3 a}(91 \%)$ as a colorless solid. ${ }^{1} \mathrm{H}$ NMR $\left(500 \mathrm{MHz}, \mathrm{CDCl}_{3}\right) \delta: 9.11(\mathrm{~s}, 1 \mathrm{H}), 8.24(\mathrm{~s}, 1 \mathrm{H}), 8.03(\mathrm{~d}, 1 \mathrm{H}, J=8.5 \mathrm{~Hz}), 7.63 \quad(\mathrm{~m}$, $3 \mathrm{H}), 7.49(\mathrm{~m}, 3 \mathrm{H}), 7.31-7.18(\mathrm{~m}, 3 \mathrm{H}), 7.08-6.99(\mathrm{~m}, 3 \mathrm{H}), 6.62 \quad(\mathrm{dd}, 1 \mathrm{H}, J=8.0$, $1.5 \mathrm{~Hz}) ;{ }^{13} \mathrm{C}$ NMR $\left(125 \mathrm{MHz}, \mathrm{CDCl}_{3}\right) \delta: 155.5 \quad(\mathrm{q}, J=36.5 \mathrm{~Hz}), 140.7,136.7$, $136.3,134.3,133.9,132.0,131.4,131.0,130.8,130.2,129.0,128.5,128.4,126.9$, $124.2,123.9,118.9 \quad(\mathrm{q}, J=278.6 \mathrm{~Hz})$.

Compound $\mathbf{4 a}^{3}$ : A $100 \mathrm{~mL}$ fask was charged with $\mathbf{3 a}(0.367 \mathrm{~g}, 0.85 \mathrm{mmol})$, potassium carbonate $(0.587 \mathrm{~g}, 4.25 \mathrm{mmol})$, water $(2 \mathrm{~mL})$ and methanol $(40 \mathrm{~mL})$. After the mixture had been refluxed for $1 \mathrm{~h}$, the reaction mixture was quenched by the addition of aqueous $\mathrm{NH}_{4} \mathrm{Cl}$. After extraction with ethyl acetate, the organic layer was dried over $\mathrm{MgSO}_{4}$ and filtered. The solvent was evaporated, and the residue was chromatographed (2.5:7.5 ethylacetate / hexane) to give $0.162 \mathrm{~g}$ of $\mathbf{4 a}(98 \%)$ as a colorless solid. ${ }^{1} \mathrm{H}$ NMR (500 $\left.\mathrm{MHz}, \mathrm{CDCl}_{3}\right) \delta: 8.32(\mathrm{~s}, 1 \mathrm{H}), 7.66(\mathrm{~d}, 2 \mathrm{H}, J=7.5 \mathrm{~Hz}), 7.63 \quad(\mathrm{~d}, 1 \mathrm{H}, J=7.5 \mathrm{~Hz})$, $7.45(\mathrm{~m}, 3 \mathrm{H}), 7.33(\mathrm{t}, 1 \mathrm{H}, J=7.5 \mathrm{~Hz}), 7.20(\mathrm{dt}, 1 \mathrm{H}, J=8.0,1.0 \mathrm{~Hz}), 7.13(\mathrm{t}, 1 \mathrm{H}, J=$ $7.5 \mathrm{~Hz}), 6.82(\mathrm{~d}, 1 \mathrm{H}, J=1.5 \mathrm{~Hz})$.

Compound 3b: LHMDS (1.0M in THF, 3.9mL, $3.9 \mathrm{mmol})$ was added to a THF solution $(20 \mathrm{~mL})$ of sulfone $2(0.677 \mathrm{~g}, 1.97 \mathrm{mmol})$ at $-78{ }^{\circ} \mathrm{C}$, and the mixture was stirred for $30 \mathrm{~min}$. Thiophene-2-carboxaldehyde $(0.331 \mathrm{~g}, 2.95 \mathrm{mmol})$ in THF $(6 \mathrm{~mL})$ was added dropwise at this temperature. After an additional $1 \mathrm{~h}, \mathrm{ClP}(\mathrm{O})(\mathrm{OEt})_{2}(0.427$ $\mathrm{mL}, 2.95 \mathrm{mmol})$ was added at $-78^{\circ} \mathrm{C}$ and the mixture was stirred at room temperature for $2 \mathrm{~h}$. Potassium $t$-butoxide $(0.722 \mathrm{~g}, 5.91 \mathrm{mmol})$ was added at $0{ }^{\circ} \mathrm{C}$. After the 
mixture had been stirred at the same temperature for $1 \mathrm{~h}$, the reaction mixture was quenched by the addition of aqueous $\mathrm{NH}_{4} \mathrm{Cl}$. After extraction with ethyl acetate, the organic layer was dried over $\mathrm{MgSO}_{4}$ and filtered. The solvent was evaporated and the residue was chromatographed (3:7 ethyl acetate / hexane) to give $0.714 \mathrm{~g}$ of $\mathbf{3 b}(83 \%)$ as a light yellow solid. ${ }^{1} \mathrm{H}$ NMR $\left(500 \mathrm{MHz}, \mathrm{CDCl}_{3}\right) \delta: 9.17(\mathrm{~s}, 1 \mathrm{H}), 8.25(\mathrm{~s}, 1 \mathrm{H}), 8.13$ $(\mathrm{d}, 1 \mathrm{H}, J=8.0 \mathrm{~Hz}), 7.65-7.28(\mathrm{~m}, 8 \mathrm{H}), 7.12(\mathrm{t}, 1 \mathrm{H}, J=7.5 \mathrm{~Hz}), 7.00(\mathrm{~m}, 1 \mathrm{H}), 6.58(\mathrm{dd}$, $1 \mathrm{H}, J=7.5,1.5 \mathrm{~Hz}) ;{ }^{13} \mathrm{C} \mathrm{NMR}\left(125 \mathrm{MHz}, \mathrm{CDCl}_{3}\right) \delta: 155.3(\mathrm{q}, J=38.1 \mathrm{~Hz}), 137.1$, $135.5,135.2,135.0,134.2,133.9,133.0,132.7,132.5,131.4,129.1,128.5,127.4$, $127.1,124.3,122.8,116.8(\mathrm{q}, J=287.8 \mathrm{~Hz})$.

Compound $4 \mathbf{b}^{4}$ : A $100 \mathrm{~mL}$ fask was charged with $3 \mathbf{b}(0.270 \mathrm{~g}, 0.617 \mathrm{mmol})$, potassium carbonate $(0.426 \mathrm{~g}, 3.08 \mathrm{mmol})$, water $(1.5 \mathrm{~mL})$ and methanol $(20 \mathrm{~mL})$. After the mixture had been refluxed for $1 \mathrm{~h}$, the reaction mixture was quenched by the addition of aqueous $\mathrm{NH}_{4} \mathrm{Cl}$. After extraction with ethyl acetate, the organic layer was dried over $\mathrm{MgSO}_{4}$ and filtered. The solvent was evaporated, and the residue was chromatographed (2.5:7.5 ethylacetate / hexane) to give $0.098 \mathrm{~g}$ of $\mathbf{4 b}(80 \%)$ as a colorless solid. ${ }^{1} \mathrm{H}$ $\operatorname{NMR}\left(500 \mathrm{MHz}, \mathrm{CDCl}_{3}\right) \delta: 8.20(\mathrm{~s}, 1 \mathrm{H}), 7.59(\mathrm{~d}, 1 \mathrm{H}, J=8.0 \mathrm{~Hz}), 7.37(\mathrm{~d}, 1 \mathrm{H}, J=8.5$ $\mathrm{Hz}), 7.28(\mathrm{~d}, 1 \mathrm{H}, J=5.0 \mathrm{~Hz}), 7.26(\mathrm{~d}, 1 \mathrm{H}, J=5.0 \mathrm{~Hz}), 7.20(\mathrm{t}, 1 \mathrm{H}, J=7.5 \mathrm{~Hz}), 7.12(\mathrm{~m}$, $2 \mathrm{H}), 6.72(\mathrm{~s}, 1 \mathrm{H})$.

Compound 3c: LHMDS (1.0 M in THF, $1.48 \mathrm{~mL}, 1.48 \mathrm{mmol}$ ) was added to a THF solution $(6 \mathrm{~mL})$ of sulfone $2(0.231 \mathrm{~g}, 0.672 \mathrm{mmol})$ at $-78{ }^{\circ} \mathrm{C}$, and the mixture was stirred for $30 \mathrm{~min}$. Cinnamaldehyde $(0.195 \mathrm{~g}, 1.48 \mathrm{mmol})$ in THF $(4 \mathrm{~mL})$ was added dropwise at this temperature. After an additional $1 \mathrm{~h}, \mathrm{ClP}(\mathrm{O})(\mathrm{OEt})_{2}(0.214 \mathrm{~mL}, 1.48$ mmol) was added at $-78{ }^{\circ} \mathrm{C}$ and the mixture was stirred at room temperature for $2 \mathrm{~h}$. Potassium $t$-butoxide $(0.328 \mathrm{~g}, 2.68 \mathrm{mmol})$ was added at $0{ }^{\circ} \mathrm{C}$. After the mixture had been stirred at the same temperature for $1 \mathrm{~h}$, the reaction mixture was quenched by the addition of aqueous $\mathrm{NH}_{4} \mathrm{Cl}$. After extraction with ethyl acetate, the organic layer was dried over $\mathrm{MgSO}_{4}$ and filtered. The solvent was evaporated, and the residue was chromatographed (2.5:7.5 ethyl acetate / hexane) to give $0.243 \mathrm{~g}$ of $\mathbf{3 c}(79 \%)$ as a colorless solid. ${ }^{1} \mathrm{H}$ NMR $\left(500 \mathrm{MHz}, \mathrm{CDCl}_{3}\right) \delta: 9.28(\mathrm{~s}, 1 \mathrm{H}), 8.04(\mathrm{~d}, 1 \mathrm{H}, J=8.5 \mathrm{~Hz})$, $7.83(\mathrm{~d}, 1 \mathrm{H}, J=11.5 \mathrm{~Hz}), 7.62(\mathrm{~m}, 3 \mathrm{H}), 7.49(\mathrm{~m}, 3 \mathrm{H}), 7.29(\mathrm{~s}, 5 \mathrm{H}), 7.14(\mathrm{~d}, 1 \mathrm{H}, J=$ $15.5 \mathrm{~Hz}), 7.09$ (d, $1 \mathrm{H}, J=7.5 \mathrm{~Hz}), 6.63$ (dd, $1 \mathrm{H}, J=7.5,1.0 \mathrm{~Hz}), 6.30$ (dd, $1 \mathrm{H}, J=15.5$, $11.5 \mathrm{~Hz}) ;{ }^{13} \mathrm{C}$ NMR $\left(125 \mathrm{MHz}, \mathrm{CDCl}_{3}\right) \delta: 155.9(\mathrm{q}, J=37.5 \mathrm{~Hz}), 145.3,141.7,137.6$, $136.1,135.0,134.7,133.8,132.8,130.7,130.0,129.0,128.8,128.2,127.7,126.3$, $124.1,123.4,121.2,119.1$ (q, $J=286.8 \mathrm{~Hz})$.

Compound $4 \mathbf{c}^{5}$ : A $100 \mathrm{~mL}$ fask was charged with 3c $(0.236 \mathrm{~g}, 0.517 \mathrm{mmol})$, potassium carbonate $(0.357 \mathrm{~g}, 2.58 \mathrm{mmol})$, water $(1.5 \mathrm{~mL})$ and methanol $(20 \mathrm{~mL})$. After the mixture had been refluxed for $3 \mathrm{~h}$, the reaction mixture was quenched by the addition of aqueous $\mathrm{NH}_{4} \mathrm{Cl}$. After extraction with ethyl acetate, the organic layer was dried over $\mathrm{MgSO}_{4}$ and filtered. The solvent was evaporated, and the residue was chromatographed (2.5:7.5 ethyl acetate / hexane) to give $0.061 \mathrm{~g}$ of $\mathbf{4 c}(54 \%)$ as a colorless solid. ${ }^{1} \mathrm{H}$ NMR $\left(500 \mathrm{MHz}, \mathrm{CDCl}_{3}\right) \delta: 8.24(\mathrm{~s}, 1 \mathrm{H}), 7.58(\mathrm{~d}, 1 \mathrm{H}, J=8.0 \mathrm{~Hz}), 7.50(\mathrm{~d}, 2 \mathrm{H}, J=7.5$ $\mathrm{Hz}), 7.38(\mathrm{~m}, 3 \mathrm{H}), 7.28(\mathrm{~d}, 1 \mathrm{H}, J=7.5 \mathrm{~Hz}), 7.20(\mathrm{t}, 1 \mathrm{H}, J=8.0 \mathrm{~Hz}), 7.14(\mathrm{~d}, 1 \mathrm{H}, J=16.5$ $\mathrm{Hz}), 7.09(\mathrm{~d}, 1 \mathrm{H}, J=7.5 \mathrm{~Hz}), 6.92(\mathrm{~d}, 1 \mathrm{H}, J=16.5 \mathrm{~Hz}), 6.61(\mathrm{~s}, 1 \mathrm{H})$. 
Compound $6^{6}$ : A $300 \mathrm{~mL}$ flask was charged with lithium aluminium hydride (3.68 g, 97 mmol) in THF $(80 \mathrm{~mL})$ and cooled to $0{ }^{\circ} \mathrm{C}$. $N$-Methyl anthranillic acid methyl ester 5 $(10.69 \mathrm{~g}, 64.7 \mathrm{mmol})$ in THF $(20 \mathrm{~mL})$ was added dropwise. After the mixture had been stirred at room temperature for $3 \mathrm{~h}$, the reaction was quenched by the dropwise addition of cold water and extracted with ethyl acetate. The extract was washed with brine, dried over $\mathrm{MgSO}_{4}$ and filtered. The solvent was evaporated and the residue was chromatographed (4:6 ethyl acetate / hexane) to give $7.80 \mathrm{~g}$ of $6(88 \%)$ as a yellow oil. ${ }^{1} \mathrm{H}$ NMR $\left(500 \mathrm{MHz}, \mathrm{CDCl}_{3}\right) \delta: 7.27(\mathrm{~m}, 1 \mathrm{H}), 7.06(\mathrm{~d}, 1 \mathrm{H}, J=7.5 \mathrm{~Hz}), 6.68(\mathrm{~m}, 2 \mathrm{H})$, 4.65 (s, 2H), 2.87(s, 3H); ${ }^{13} \mathrm{C}$ NMR $\left(125 \mathrm{MHz}, \mathrm{CDCl}_{3}\right) \delta: 148.4,129.6,128.8,124.2$, $116.3,110.0,64.6,30.2$.

Compound $7^{6}$ : A $200 \mathrm{~mL}$ fask was charged with 6 (7.62 g, $\left.55.6 \mathrm{mmol}\right)$ in THF $(70 \mathrm{~mL})$ and $(\mathrm{BOC})_{2} \mathrm{O}(13.3 \mathrm{~g}, 61.2 \mathrm{mmol})$ in THF $(30 \mathrm{~mL})$ was added. After the mixture had been refluxed for $5.5 \mathrm{~h}$, stirring was continued at room temperature for $12 \mathrm{~h}$. The solvent was evaporated and the residue was chromatographed (3.5:6.5 ethyl acetate / hexane) to give $10.01 \mathrm{~g}$ of $7(76 \%)$ as a yellow liquid. ${ }^{1} \mathrm{H} \mathrm{NMR}\left(500 \mathrm{MHz}, \mathrm{CDCl}_{3}\right) \delta$ : $7.53(\mathrm{~m}, 1 \mathrm{H}), 7.32-7.06(\mathrm{~m}, 3 \mathrm{H}), 4.60 \& 4.45$ (br, 2H), 3.50(br, 1H), $3.20 \quad(\mathrm{~s}, 3 \mathrm{H})$, $1.53 \& 1.33$ (br, 9H).

Compound $\mathbf{8}^{6}$ : A $300 \mathrm{~mL}$ flask was charged with $7(9.85 \mathrm{~g}, 41.5 \mathrm{mmol})$ and triphenylphosphine $(13.08 \mathrm{~g}, 49.8 \mathrm{mmol})$ in THF $(180 \mathrm{~mL})$ and cooled to $0{ }^{\circ} \mathrm{C}$. NBromosuccinimide ( $8.87 \mathrm{~g}, 49.8 \mathrm{mmol}$ ) was added at this temperature and the stirring was continued at room temperature for $2 \mathrm{~h}$. The solid formed was filtered and washed with ethyl acetate. The filtrate was evaporated and the residue was chromatographed (2.5: 7.5 ethyl acetate / heaxane) to give $10.45 \mathrm{~g}$ of 8 (84 \%) as a colorless solid. $\quad{ }^{1} \mathrm{H} \mathrm{NMR} \quad\left(500 \quad \mathrm{MHz}, \mathrm{CDCl}_{3}\right) \quad \delta: 7.45(\mathrm{~m}, 1 \mathrm{H}), 7.31-7.26(\mathrm{~m}$, 2H), $7.11(\mathrm{br}, 1 \mathrm{H}), 4.52(\mathrm{~d}, 1 \mathrm{H}, J=10.5 \mathrm{~Hz}), 4.39(\mathrm{~d}, 1 \mathrm{H}, J=10.0 \mathrm{~Hz}), 3.22(\mathrm{~s}, 3 \mathrm{H})$, $1.53 \& 1.33$ (br, 9H).

Compound 9: A $200 \mathrm{~mL}$ flask was charged with 8 (10.16 g, $33.8 \mathrm{mmol})$, benzenesulfinic acid sodium salt dihydrate (6.67 $\mathrm{g}, 40.6 \mathrm{mmol})$ and DMF (120 $\mathrm{mL}$ ). After the mixture had been stirred at $80{ }^{\circ} \mathrm{C}$ for $12 \mathrm{~h}$, the reaction mixture was cooled to room temperature. After usual workup with water and ethyl acetate, the solvent was evaporated and the residue was chromatographed (3.5:6.5 ethyl acetate / hexane) to give $10.75 \mathrm{~g}$ of $9(88 \%)$ as a colorless solid. ${ }^{1} \mathrm{H} \mathrm{NMR}\left(500 \mathrm{MHz}, \mathrm{CDCl}_{3}\right) \delta$ : $7.70(\mathrm{~d}, 2 \mathrm{H}, J=7.5 \mathrm{~Hz}), 7.63(\mathrm{t}, 1 \mathrm{H}, J=7.5 \mathrm{~Hz}), 7.50-7.06(\mathrm{~m}, 6 \mathrm{H}), 4.49(\mathrm{~d}, 1 \mathrm{H}, J=$ $12.0 \mathrm{~Hz}), 4.18(\mathrm{~d}, 1 \mathrm{H}, J=12.0 \mathrm{~Hz}), 2.97 \& 2.76(\mathrm{br}, 3 \mathrm{H}), 1.49 \& 1.27(\mathrm{br}, 9 \mathrm{H}) ;{ }^{13} \mathrm{C}$ NMR $\left(125 \mathrm{MHz}, \mathrm{CDCl}_{3}\right) \delta: 154.4,143.5,138.6,133.6,131.9,131.4,129.7,128.9$, $128.4,127.0,126.7,125.8,80.2,58.6,57.4,37.7,36.8,28.0$.

Compound 10: BuLi (1.33 $\mathrm{M}$ in hexane, $2.75 \mathrm{~mL}, 3.65 \mathrm{mmol})$ was added to a THF solution $(35 \mathrm{~mL})$ of sulfone $9(1.20 \mathrm{~g}, 3.32 \mathrm{mmol})$ at $-78{ }^{\circ} \mathrm{C}$, and the mixture was stirred for $30 \mathrm{~min}$. Benzaldehyde $(0.422 \mathrm{~g}, 3.98 \mathrm{mmol})$ in THF $(8 \mathrm{~mL})$ was added dropwise at this temperature. After an additional $1 \mathrm{~h}, \mathrm{ClP}(\mathrm{O})(\mathrm{OEt})_{2}(0.57 \mathrm{~mL}, 3.98 \mathrm{mmol})$ was added at $-78{ }^{\circ} \mathrm{C}$ and the mixture was stirred at room temperature for $2 \mathrm{~h}$. Potassium $t$ butoxide $(1.21 \mathrm{~g}, 9.96 \mathrm{mmol})$ was added at $0{ }^{\circ} \mathrm{C}$. After the mixture had been stirred at 
the same temperature for $1 \mathrm{~h}$, the solvent was evaporated and the residue was dissolved in a premixed solution of ethyl acetate $(56 \mathrm{~mL}) / 12 \mathrm{M} \mathrm{HCl}(24 \mathrm{~mL})$ and stirred at room temperature for $2 \mathrm{~h}$. The reaction mixture was neutralized with solid $\mathrm{NaHCO}_{3}$, extracted with ethyl acetate, dried over $\mathrm{MgSO}_{4}$ and filtered. The solvent was evaporated and the residue was chromatographed (2.5:7.5 ethyl acetate / hexane) to give $1.06 \mathrm{~g}$ of $10(92 \%)$ as a yellow solid. ${ }^{1} \mathrm{H}$ NMR $\left(500 \mathrm{MHz}, \mathrm{CDCl}_{3}\right) \delta: 8.05(\mathrm{~s}, 1 \mathrm{H})$, $7.66(\mathrm{dd}, 2 \mathrm{H}, J=8.5,1.5 \mathrm{~Hz}), 7.56(\mathrm{~m}, 1 \mathrm{H}), 7.42(\mathrm{t}, 2 \mathrm{H}, J=8.0 \mathrm{~Hz}), 7.29-7.17(\mathrm{~m}, 6 \mathrm{H})$, 6.59-6.48 (m, 3H), $3.98(\mathrm{br}, 1 \mathrm{H}), 2.57(\mathrm{~d}, 3 \mathrm{H}, J=3.5 \mathrm{~Hz}) ;{ }^{13} \mathrm{C}$ NMR $\left(125 \mathrm{MHz}, \mathrm{CDCl}_{3}\right)$ $\delta: 147.9,139.6,138.2(2), 133.2,132.5,131.3,130.8,130.5,130.2,128.7,128.6,128.5$, $116.7,115.4,110.2,30.4$.

Compound 11a ${ }^{7}$ : A $50 \mathrm{~mL}$ flask was charged with $\mathbf{1 0}(0.288 \mathrm{~g}, 0.82 \mathrm{mmol})$ in THF (15 $\mathrm{mL}$ ) and cooled to $0{ }^{\circ} \mathrm{C}$. LHMDS (1M in THF, $\left.1.23 \mathrm{~mL}, 1.23 \mathrm{mmol}\right)$ was added slowly. After the mixture had been stirred at $0{ }^{\circ} \mathrm{C}$ for $1 \mathrm{~h}$, and then at room temperature for 10 min., methyl iodide $(0.154 \mathrm{~mL}, 2.47 \mathrm{mmol})$ was added. After the mixture had been stirred at room temperature for $1 \mathrm{~h}$, the reaction was quenched by the addition of aqueous $\mathrm{NH}_{4} \mathrm{Cl}$ and extracted with ethyl acetate. The extract was dried over $\mathrm{MgSO}_{4}$ and filtered. The solvent was evaporated and chromatographed (2.5:7.5 $\mathrm{CH}_{2} \mathrm{Cl}_{2} /$ hexane) to give $0.149 \mathrm{~g}$ of $11 \mathrm{a}(82 \%)$ as a colorless solid. ${ }^{1} \mathrm{H}$ NMR $\left(500 \mathrm{MHz}, \mathrm{CDCl}_{3}\right) \delta: 7.61(\mathrm{~d}$, $1 \mathrm{H}, J=7.5 \mathrm{~Hz}), 7.50(\mathrm{t}, 2 \mathrm{H}, J=7.5 \mathrm{~Hz}), 7.42(\mathrm{~m}, 3 \mathrm{H}), 7.34(\mathrm{~d}, 1 \mathrm{H}, J=8.5 \mathrm{~Hz}), 7.27(\mathrm{t}$, $1 \mathrm{H}, J=8.0 \mathrm{~Hz}), 7.17(\mathrm{t}, 1 \mathrm{H}, J=8.0 \mathrm{~Hz}), 3.61(\mathrm{~s}, 3 \mathrm{H}), 2.28(\mathrm{~s}, 3 \mathrm{H}) ;{ }^{13} \mathrm{C} \mathrm{NMR}(125$ $\left.\mathrm{MHz}, \mathrm{CDCl}_{3}\right) \delta: 137.6,137.1,132.0,130.6,128.3,128.2,127.7,121.6,119.0,118.7$, 109.1, 108.5, 30.9, 9.3.

Compound $11 \mathbf{b}^{7}$ : A $50 \mathrm{~mL}$ flask was charged with $10(0.300 \mathrm{~g}, 0.86 \mathrm{mmol})$ in THF (15 $\mathrm{mL}$ ) and cooled to $0{ }^{\circ} \mathrm{C}$. LHMDS ( $1 \mathrm{M}$ in THF, $\left.1.30 \mathrm{~mL}, 1.29 \mathrm{mmol}\right)$ was added slowly. After the mixture had been stirred at $0^{\circ} \mathrm{C}$ for $1 \mathrm{~h}$, and then at room temperature for $10 \mathrm{~min}$., ethyl iodide $(0.355 \mathrm{~mL}, 3.44 \mathrm{mmol})$ was added. After the mixture had been stirred at room temperature for $1 \mathrm{~h}$, the reaction was quenched by the addition of aqueous $\mathrm{NH}_{4} \mathrm{Cl}$ and extracted with ethyl acetate. The extract was dried over $\mathrm{MgSO}_{4}$ and filtered. The solvent was evaporated and chromatographed (2.5:7.5 $\mathrm{CH}_{2} \mathrm{Cl}_{2}$ / hexane) to give $0.173 \mathrm{~g}$ of $\mathbf{1 1 b}(86 \%)$ as a colorless liquid. ${ }^{1} \mathrm{H}$ NMR $(500 \mathrm{MHz}$, $\left.\mathrm{CDCl}_{3}\right) \delta: 7.66(\mathrm{~d}, 1 \mathrm{H}, J=8.0 \mathrm{~Hz}), 7.48-7.33(\mathrm{~m}, 6 \mathrm{H}), 7.26(\mathrm{~m}, 1 \mathrm{H}), 7.16(\mathrm{~m}, 1 \mathrm{H})$, $3.57(\mathrm{~s}, 3 \mathrm{H}), 2.73(\mathrm{q}, 2 \mathrm{H}, J=8.0 \mathrm{~Hz}), 1.24(\mathrm{t}, 3 \mathrm{H}, J=8.0 \mathrm{~Hz}) ;{ }^{13} \mathrm{C}$ NMR $(125 \mathrm{MHz}$, $\left.\mathrm{CDCl}_{3}\right) \delta: 137.2,137.1,132.2,130.5,128.2,127.8,127.3,121.5,119.0,115.3,109.3$, $30.7,17.8,16.0$.

Compound 11 $\mathrm{c}^{8}$ : A $50 \mathrm{~mL}$ flask was charged with $\mathbf{1 0}(0.283 \mathrm{~g}, 0.81 \mathrm{mmol})$ in THF (15 $\mathrm{mL})$ and cooled to $0{ }^{\circ} \mathrm{C}$. LHMDS (1 M in THF, $\left.1.21 \mathrm{~mL}, 1.21 \mathrm{mmol}\right)$ was added slowly. After the mixture had been stirred at $0{ }^{\circ} \mathrm{C}$ for $1 \mathrm{~h}$, and then at room temperature for $10 \mathrm{~min}$., propyl iodide $(0.316 \mathrm{~mL}, 3.24 \mathrm{mmol})$ was added. After the mixture had been stirred at room temperature for $1 \mathrm{~h}$, the reaction was quenched by the addition of aqueous $\mathrm{NH}_{4} \mathrm{Cl}$ and extracted with ethyl acetate. The extract was dried over $\mathrm{MgSO}_{4}$ and filtered. The solvent was evaporated and chromatographed $\left(2.5: 7.5 \mathrm{CH}_{2} \mathrm{Cl}_{2} /\right.$ hexane) to give $0.169 \mathrm{~g}$ of $11 \mathrm{c}(84 \%)$ as a colorless liquid. ${ }^{1} \mathrm{H}$ NMR $(500 \mathrm{MHz}$, $\left.\mathrm{CDCl}_{3}\right) \delta: 7.65(\mathrm{~d}, 1 \mathrm{H}, J=8.0 \mathrm{~Hz}), 7.49-7.32(\mathrm{~m}, 6 \mathrm{H}), 7.24(\mathrm{t}, 1 \mathrm{H}, J=4.0 \mathrm{~Hz}), 7.15(\mathrm{t}$, $1 \mathrm{H}, J=7.5 \mathrm{~Hz}), 3.57(\mathrm{~s}, 3 \mathrm{H}), 2.67(\mathrm{t}, 2 \mathrm{H}, J=8.0 \mathrm{~Hz}), 1.67(\mathrm{~m}, 2 \mathrm{H}), 0.89(\mathrm{t}, 3 \mathrm{H}, J=7.5$ $\mathrm{Hz}) ;{ }^{13} \mathrm{C} \mathrm{NMR}\left(125 \mathrm{MHz}, \mathrm{CDCl}_{3}\right) \delta: 137.6,137.1,132.9,130.6,128.2,127.8,127.7$, 
Compound 11d: A $50 \mathrm{~mL}$ flask was charged with $\mathbf{1 0}(0.282 \mathrm{~g}, 0.80 \mathrm{mmol})$ in THF (15 $\mathrm{mL})$ and cooled to $0{ }^{\circ} \mathrm{C}$. LHMDS $(1 \mathrm{M}$ in THF, $1.21 \mathrm{~mL}, 1.21 \mathrm{mmol})$ was added slowly. After the mixture had been stirred at $0{ }^{\circ} \mathrm{C}$ for $1 \mathrm{~h}$, and then at room temperature for $10 \mathrm{~min}$., allyl iodide $(0.295 \mathrm{~mL}, 3.23 \mathrm{mmol})$ was added. After the mixture had been stirred at room temperature for $1 \mathrm{~h}$, the reaction was quenched by the addition of aqueous $\mathrm{NH}_{4} \mathrm{Cl}$ and extracted with ethyl acetate. The extract was dried over $\mathrm{MgSO}_{4}$ and filtered. The solvent was evaporated and chromatographed (2.5:7.5 $\mathrm{CH}_{2} \mathrm{Cl}_{2} /$ hexane) to give $0.167 \mathrm{~g}$ of $\mathbf{1 1 d}(84 \%)$ as a colorless liquid. ${ }^{1} \mathrm{H} \mathrm{NMR}\left(500 \mathrm{MHz}, \mathrm{CDCl}_{3}\right)$ $\delta: 7.63(\mathrm{~d}, 1 \mathrm{H}, J=7.5 \mathrm{~Hz}), 7.49-7.39(\mathrm{~m}, 5 \mathrm{H}), 7.35(\mathrm{~d}, 1 \mathrm{H}, J=8.5 \mathrm{~Hz}), 7.27(\mathrm{t}, 1 \mathrm{H}, J=$ $7.5 \mathrm{~Hz}), 7.15(\mathrm{t}, 1 \mathrm{H}, J=7.5 \mathrm{~Hz}), 6.05(\mathrm{~m}, 1 \mathrm{H}), 5.05(\mathrm{~m}, 2 \mathrm{H}), 3.62(\mathrm{~s}, 3 \mathrm{H}), 3.44(\mathrm{~d}, 2 \mathrm{H}$, $J=6.0 \mathrm{~Hz}) ;{ }^{13} \mathrm{C}$ NMR $\left(125 \mathrm{MHz}, \mathrm{CDCl}_{3}\right) \delta: 138.0,137.9,137.2,131.7,130.5,128.2$, $127.9,127.7,121.6,119.2,119.1,114.5,110.5,109.3,30.8,29.2$. Anal. Calcd for $\mathrm{C}_{18} \mathrm{H}_{17} \mathrm{~N}$ : C, 87.41; H, 6.93; N, 5.66; Found C, 87.12; H, 7.12, N, 5.57.

Compound 11e: A $50 \mathrm{~mL}$ flask was charged with $10(0.277 \mathrm{~g}, 0.79 \mathrm{mmol})$ in THF (15 $\mathrm{mL})$ and cooled to $0{ }^{\circ} \mathrm{C}$. LHMDS (1 M in THF, $\left.1.20 \mathrm{~mL}, 1.20 \mathrm{mmol}\right)$ was added slowly. After the mixture had been stirred at $0{ }^{\circ} \mathrm{C}$ for $1 \mathrm{~h}$, and then at room temperature for $10 \mathrm{~min}$., ethyl bromoacetate $(0.352 \mathrm{~mL}, 3.17 \mathrm{mmol})$ was added. After the mixture had been stirred at room temperature for $1 \mathrm{~h}$, the reaction was quenched by the addition of aqueous $\mathrm{NH}_{4} \mathrm{Cl}$ and extracted with ethyl acetate. The extract was dried over $\mathrm{MgSO}_{4}$ and filtered. The solvent was evaporated and chromatographed (1.5:8.5 ethyl acetate / hexane) to give $0.188 \mathrm{~g}$ of $11 \mathrm{e}(81 \%)$ as a yellow liquid. ${ }^{1} \mathrm{H} \mathrm{NMR}\left(500 \mathrm{MHz}, \mathrm{CDCl}_{3}\right)$ $\delta: 7.66(\mathrm{~d}, 1 \mathrm{H}, J=8.0 \mathrm{~Hz}), 7.51-7.43(\mathrm{~m}, 5 \mathrm{H}), 7.35(\mathrm{~d}, 1 \mathrm{H}, J=8.0 \mathrm{~Hz}), 7.28(\mathrm{dd}, 1 \mathrm{H}, J$ $=7.0,1.0 \mathrm{~Hz}), 7.18(\mathrm{dt}, 1 \mathrm{H}, J=8.0,1.0 \mathrm{~Hz}), 4.15(\mathrm{q}, 2 \mathrm{H}, J=7.0 \mathrm{~Hz}), 3.65(\mathrm{~s}, 2 \mathrm{H}), 3.62$ $(\mathrm{s}, 3 \mathrm{H}), 1.25$ (t, 3H, $J=7.0 \mathrm{~Hz}) ;{ }^{13} \mathrm{C} \mathrm{NMR}\left(125 \mathrm{MHz}, \mathrm{CDCl}_{3}\right) \delta: 172.3,139.2,137.1$, 131.1,130.6, 128.3, 128.2, 127.5, 121.9, 119.6, 119.0, 109.4, 105.7, 60.6, 31.1, 30.9, 14.1. Anal. Calcd for $\mathrm{C}_{19} \mathrm{H}_{19} \mathrm{NO}_{3}$ : C, 77.79; H, 6.53; N, 4.77; Found C, 77.74; H, 6.66, N, 4.77.

Compound 11f: A $50 \mathrm{~mL}$ flask was charged with 10 (0.284 g, $0.81 \mathrm{mmol})$ in THF (15 $\mathrm{mL})$ and cooled to $0{ }^{\circ} \mathrm{C}$. LHMDS (1 M in THF, $\left.1.21 \mathrm{~mL}, 1.21 \mathrm{mmol}\right)$ was added slowly. After the mixture had been stirred at $0{ }^{\circ} \mathrm{C}$ for $1 \mathrm{~h}$, and then at room temperature for 10 min., $N, N$-diethyl chloroacetamide $(0.446 \mathrm{~mL}, 3.24 \mathrm{mmol})$ was added. After the mixture had been stirred at room twemperature for $1 \mathrm{~h}$, the reaction was quenched by the addition of aqueous $\mathrm{NH}_{4} \mathrm{Cl}$ and extracted with ethyl acetate. The extract was dried over $\mathrm{MgSO}_{4}$ and filtered. The solvent was evaporated and chromatographed (2.5:7.5 ethyl acetate / hexane) to give $0.223 \mathrm{~g}$ of $\mathbf{1 1 f}(86 \%)$ as a colorless solid. ${ }^{1} \mathrm{H}$ NMR (500 $\left.\mathrm{MHz}, \mathrm{CDCl}_{3}\right) \delta: 7.75(\mathrm{~d}, 1 \mathrm{H}, J=8.0 \mathrm{~Hz}), 7.51-7.41(\mathrm{~m}, 5 \mathrm{H}), 7.34(\mathrm{~d}, 1 \mathrm{H}, J=8.0 \mathrm{~Hz})$, $7.25(\mathrm{t}, 1 \mathrm{H}, J=8.0 \mathrm{~Hz}), 7.15(\mathrm{t}, 1 \mathrm{H}, J=8.0 \mathrm{~Hz}), 3.72(\mathrm{~s}, 2 \mathrm{H}), 3.62(\mathrm{~s}, 3 \mathrm{H}), 3.33(\mathrm{q}, 2 \mathrm{H}$, $J=7.0 \mathrm{~Hz}), 3.11(\mathrm{q}, 2 \mathrm{H}, J=7.0 \mathrm{~Hz}), 1.06(\mathrm{t}, 3 \mathrm{H}, J=7.0 \mathrm{~Hz}), 0.86(\mathrm{t}, 3 \mathrm{H}, J=7.0 \mathrm{~Hz})$; ${ }^{13} \mathrm{C}$ NMR $\left(125 \mathrm{MHz}, \mathrm{CDCl}_{3}\right) \delta: 170.4,138.2,137.2,131.4,130.5,128.4,128.1,127.6$, 121.8, 119.6, 119.5, 109.1, 107.0, 41.9, 40.7, 31.0, 30.9, 13.8, 12.9. Anal. Calcd for $\mathrm{C}_{21} \mathrm{H}_{24} \mathrm{~N}_{2} \mathrm{O}: \mathrm{C}, 78.71 ; \mathrm{H}, 7.55, \mathrm{~N}, 8.74$; Found $\mathrm{C}, 78.57 ; \mathrm{H}, 7.56 ; \mathrm{N}, 8.60$.

Compound 11. $\mathbf{g}^{9}$ : A $50 \mathrm{~mL}$ flask was charged with $\mathbf{1 0}(0.281 \mathrm{~g}, 0.80 \mathrm{mmol})$ in THF (15 
$\mathrm{mL}$ ) and cooled to $0{ }^{\circ} \mathrm{C}$. LHMDS (1 M in THF, $\left.1.20 \mathrm{~mL}, 1.20 \mathrm{mmol}\right)$ was added slowly. After the mixture had been stirred at $0{ }^{\circ} \mathrm{C}$ for $1 \mathrm{~h}$, and then at room temperature for $10 \mathrm{~min}$., benzoyl chloride $(0.467 \mathrm{~mL}, 4.02 \mathrm{mmol})$ was added. After the mixture had been stirred at room temperature for $1 \mathrm{~h}$, LHMDS (1 M in THF, $4.0 \mathrm{~mL}, 4.02 \mathrm{mmol})$ was added and stirred at room temperature for $1 \mathrm{~h}$. The reaction was quenched by the addition of aqueous $\mathrm{NH}_{4} \mathrm{Cl}$ and extracted with ethyl acetate. The extract was dried over $\mathrm{MgSO}_{4}$ and filtered. The solvent was evaporated and chromatographed (1.5:8.5 ethyl acetate / hexane) to give $0.212 \mathrm{~g}$ of $\mathbf{1 1 g}(85 \%)$ as a colorless solid. ${ }^{1} \mathrm{H}$ NMR (500 $\left.\mathrm{MHz}, \mathrm{CDCl}_{3}\right) \delta: 8.02(\mathrm{~d}, 1 \mathrm{H}, J=8.0 \mathrm{~Hz}), 7.52-7.23(\mathrm{~m}, 11 \mathrm{H}), 7.13(\mathrm{t}, 2 \mathrm{H}, J=7.5 \mathrm{~Hz})$, $3.68(\mathrm{~s}, 3 \mathrm{H}) ;{ }^{13} \mathrm{C}$ NMR $\left(125 \mathrm{MHz}, \mathrm{CDCl}_{3}\right) \delta: 198.8,146.3,140.0,137.1,130.8(2)$, $130.6,129.1,128.6,127.9,127.5,127.4,123.1,122.2,121.8,114.4,109.7,31.2$.

Compound 12: $\mathrm{BuLi}(1.33 \mathrm{M}$ in hexane, $1.45 \mathrm{~mL}, 1.93 \mathrm{mmol})$ was added to a THF solution $(20 \mathrm{~mL})$ of sulfone $9(0.636 \mathrm{~g}, 1.76 \mathrm{mmol})$ at $-78{ }^{\circ} \mathrm{C}$, and the mixture was stirred for $30 \mathrm{~min}$. 4-Chloro-benzaldehyde $(0.296 \mathrm{~g}, 2.11 \mathrm{mmol})$ in THF $(8 \mathrm{~mL})$ was added dropwise at this temperature. After an additional $1 \mathrm{~h}, \mathrm{ClP}(\mathrm{O})(\mathrm{OEt})_{2}(0.305 \mathrm{~mL}$, $2.11 \mathrm{mmol})$ was added at $-78{ }^{\circ} \mathrm{C}$ and the mixture was stirred at room temperature for $2 \mathrm{~h}$. Potassium $t$-butoxide $(0.645 \mathrm{~g}, 5.28 \mathrm{mmol})$ was added at $0{ }^{\circ} \mathrm{C}$. After the mixture had been stirred at the same temperature for $1 \mathrm{~h}$, the solvent was evaporated and the residue was dissolved in a premixed solution of ethyl acetate $(29.4 \mathrm{~mL}) / 12 \mathrm{M} \mathrm{HCl}$ $(12.6 \mathrm{~mL})$ and stirred at room temperature for $2 \mathrm{~h}$. The reaction mixture was neutralized with solid $\mathrm{NaHCO}_{3}$, extracted with ethyl acetate, dried over $\mathrm{MgSO}_{4}$ and filtered. The solvent was evaporated and the residue was chromatographed (2.5:7.5 ethyl acetate / hexane) to give $0.614 \mathrm{~g}$ of $12(91 \%)$ as a yellow solid. ${ }^{1} \mathrm{H}$ NMR (500 $\left.\mathrm{MHz}, \mathrm{CDCl}_{3}\right) \delta: 7.99(\mathrm{~s}, 1 \mathrm{H}), 7.65(\mathrm{dd}, 2 \mathrm{H}, J=8.5,1.5 \mathrm{~Hz}), 7.57(\mathrm{~m}, 1 \mathrm{H}), 7.42(\mathrm{t}, 2 \mathrm{H}$, $J=8.5 \mathrm{~Hz}), 7.28(\mathrm{~m}, 1 \mathrm{H}), 7.18(\mathrm{~d}, 2 \mathrm{H}, J=8.5 \mathrm{~Hz}), 7.10(\mathrm{~d}, 2 \mathrm{H}, J=8.5 \mathrm{~Hz}), 6.58(\mathrm{~d}$, $1 \mathrm{H}, J=8.0 \mathrm{~Hz}), 6.55(\mathrm{dt}, 1 \mathrm{H}, J=7.0,1.0 \mathrm{~Hz}), 6.47(\mathrm{dd}, 1 \mathrm{H}, J=7.0,1.0 \mathrm{~Hz}), 3.97(\mathrm{~b}$, $1 \mathrm{H}), 2.57(\mathrm{~d}, 3 \mathrm{H}, J=5.0 \mathrm{~Hz}) ;{ }^{13} \mathrm{C}$ NMR $\left(125 \mathrm{MHz}, \mathrm{CDCl}_{3}\right) \delta: 147.9,139.0,138.2$, 138.0, 136.5, 133.3, 131.4, 131.2, 131.1, 131.0, 128.9, 128.8, 128.6, 116.8, 115.0, 110.4, 30.4 .

Compound $14^{10}$ : A $50 \mathrm{~mL}$ flask was charged with 12 (0.306 g, $\left.0.79 \mathrm{mmol}\right)$ in THF (15 $\mathrm{mL})$ and cooled to $0{ }^{\circ} \mathrm{C}$. LHMDS (1 M in THF, $\left.1.20 \mathrm{~mL}, 1.19 \mathrm{mmol}\right)$ was added slowly. After the mixture had been stirred at $0{ }^{\circ} \mathrm{C}$ for $1 \mathrm{~h}$, and then at room temperature for $10 \mathrm{~min} ., 13$ ( $0.566 \mathrm{~g}, 3.18 \mathrm{mmol})$ was added. After the mixture had been stirred at room temperature for $1 \mathrm{~h}$, the reaction was quenched by the addition of aqueous $\mathrm{NH}_{4} \mathrm{Cl}$ and extracted with ethyl acetate. The extract was dried over $\mathrm{MgSO}_{4}$ and filtered. The solvent was evaporated and chromatographed (3:7 ethyl acetate / hexane) to give 0.244 g of $14(80 \%)$ as a colorless solid. ${ }^{1} \mathrm{H}$ NMR $\left(500 \mathrm{MHz}, \mathrm{CDCl}_{3}\right) \delta: 7.68(\mathrm{~d}, 1 \mathrm{H}, J=7.5$ $\mathrm{Hz}), 7.47(\mathrm{~d}, 2 \mathrm{H}, J=8.5 \mathrm{~Hz}), 7.40(\mathrm{~d}, 2 \mathrm{H}, J=8.5 \mathrm{~Hz}), 7.33(\mathrm{~d}, 1 \mathrm{H}, J=8.5 \mathrm{~Hz}), 7.25$ $(\mathrm{m}, 1 \mathrm{H}), 7.14(\mathrm{t}, 1 \mathrm{H}, J=8.0 \mathrm{~Hz}), 3.68(\mathrm{~s}, 2 \mathrm{H}), 3.60(\mathrm{~s}, 3 \mathrm{H}), 3.26(\mathrm{t}, 2 \mathrm{H}, J=7.5 \mathrm{~Hz})$, $3.10(\mathrm{t}, 2 \mathrm{H}, J=7.5 \mathrm{~Hz}), 1.53(\mathrm{~m}, 4 \mathrm{H}), 0.83(\mathrm{t}, 3 \mathrm{H}, J=7.5 \mathrm{~Hz}), 0.74(\mathrm{t}, 3 \mathrm{H}, J=7.5 \mathrm{~Hz})$; ${ }^{13} \mathrm{C}$ NMR $\left(125 \mathrm{MHz}, \mathrm{CDCl}_{3}\right) \delta: 170.7,137.3,137.1,134.3,131.8,129.9,128.6,127.6$, $122.0,119.6,119.4,109.3,107.6,49.6,47.8,30.9,30.5,22.1,20.8,11.3,11.0$.

References:

1.Makosza, M.; Golinski, J.; Baran, J. J. Org. Chem. 1984, 49, 1488. 
2.Wojciechowski, K.; Makosza, M. Synthesis 1986, 651.

3.Sezen, B; Sames,D. J. Am. Chem. Soc. 2003, 125, 5274.

4.Hudkins, R.L.; Diebold, J.L.; Marsh, F.D. J. Org. Chem. 1995, 60, 6218.

5.Cacchi, S.; Carnicelli, V.; Marinelli, F. J. Organomet. Chem. 1994, 475, 289.

6.Beak, P.; Basu, K.C.; Li, J.J. J. Org. Chem. 1999, 64, 5218.

7.Biswas, K. M. Dhara, R.; Roy, S.; Mallik, H. Tetrahedron 1984, 40, 4351.

8.Shen M.; Li, G.; Lu, B.Z.; Hossain, A.; Roschangar, F.; Farina, V.; Senanayake, C.H. Org. Lett. 2004, 6, 4129.

9.(a)Parpani, P.; Zecchi, G. J. Org. Chem. 1987, 52, 1417. (b)Szmuszkovicz, J. J. Org. Chem. 1962, 27, 511.

10.Kozikowski, A.P.; Ma, D.; Brewer, J.; Sun, S.; Costa, E.; Romeo, E.; Guidotti, A. J. Med. Chem. 1993, 36, 2908 . 